Islamic Management; Jurnal Manajemen Pendidikan Islam, Vol.I, No.1, Januari 2018

\title{
MANAJEMEN FACEBOOK DALAM PROSES PEMBELAJARAN PENDIDIKAN
}

\author{
Sarifudin, Halimah \\ Sekolah Tinggi Agama Islam Al-Hidayah Bogor \\ sarif_udin66@yahoo.com
}

\begin{abstract}
Technology is a necessity for the nation and state, at this time the science of technology is growing rapidly, the people in demand to participate following the flow of globalization, the only sala is social networking services, especially Facebook. the emergence of the phenomenon and the development of the era that is booming diseantero universe is one of them the development of technology, technological developments increasingly sophisticated able to hypnotize all humans from various layers, ranging from children, adolescents, adults to the elderly (adult elderly) parents and all educators inside and outside the school to be able to pay attention and supervise every step of the way protege, because the development of technology that is currently rampant can affect the condition of the environment and learning achievement, so the attention and supervision of parents and educators in in school and outside the school should be more vigilant. At this time the people of Indonesia know Facebook as a medium of friendship was able to sedate citizens of Indonesia to compete in mastering this social networking site. However, at the present time we find a lot of unfortunate events, criminal incidents caused by Facebook, we often encounter teenage girls in raped by friends who he just knew through Facebook network, pembegalan or other crime incidents. Therefore, there is a need for proper processing related to this social networking, if it is used into a positive sipatnya as a tool for the learning process then the results are very useful to reproduce science, or otherwise used for futility or negative things then the results not good or bad.
\end{abstract}

Keywords: Management, Facebook, Educational Learning

\section{ABSTRAK}

Teknologi merupakan suatu kebutuhan bagi bangsa dan negara, pada saat ini ilmu teknologi semakin berkembang pesat, masyarakat di tuntut untuk ikut serta mengikuti arus globalisasi, sala satunya adalah layanan jejaring social, terutama Facebook. munculnya fenomena dan perkembangan zaman yang sedang booming diseantero jagad raya ini salah satunya perkembangan teknologi, perkembangan teknologi yang semakin canggih mampu menghipnotis seluruh manusia dari berbagai lapisan, mulai dari anak-anak, remaja, dewasa sampai pada lansia (dewasa lanjut usia) hal ini menuntut orang tua dan seluruh pendidik di dalam maupun di luar sekolah untuk dapat memperhatikan dan mengawasi setiap gerakgerik langkah anak didiknya, karena perkembangan teknologi yang sedang marak saat ini dapat mempengaruhi kondisi lingkungan dan prestasi belajar, sehingga perhatian dan pengawasan orang tua serta tenaga pendidik di dalam sekolah maupun di luar sekolah harus lebih waspada. Pada saat ini masyarakat Indonesia mengenal Facebook sebagai media pertemanan ternyata mampu membius warga Indonesia untuk berlomba-lomba dalam menguasai situs jejaring sosial ini. Akan tetapi pada saat sekarang banyak sekali kita temukan kejadian-kejadian yang kurang baik, kejadian kriminal yang disebabkan oleh Facebook, sering kita jumpai anak perempuan remaja di perkosa oleh temennya yang ia baru kenal lewat jejaring Facebook, pembegalan atau kejadian-kejadian kejahatan lain sebagainnya. Oleh sebab itu perlunya ada pengolahan yang benar berkaitan dengan jejaring sosial ini, jika digunakan kedalam hal yang sipatnya positif sebagai alat untuk proses 
pembelajaran maka hasilnya sangat bermanfaat untuk memperbanyak ilmu pengetahuan, atau sebaliknya digunakan untuk kesia-siaan atau hal-hal negatif maka hasilnya kurang baik atau buruk.

Kata Kunci: manajemen, facebook, pembelajaran pendidikan

\section{PENDAHULUAN}

Dewasa ini ilmu dan teknologi telah semakin maju, canggih dan tersebar ke seluruh pelosok dunia, dan salah satu yang berkembang saat ini adalah media massa yang mempunyai peran penting dalam kehidupan sosial masyarakat.

Media menjadi arena pertarungan berbagai kepentingan untuk mengontrol masyarakat. Siapa yang mampu menguasai media, dialah pemenangnya. Membayangkan kebudayaan sebagai sesuatu kesatuan yang utuh, kukuh, dan stabil adalah mimpi di siang bolong. Pada dunia yang di dera era globalisasi, modernisme, dan postmodernisme, media mengambil peran signifikan untuk memporakporandakan struktur kebudayaan yang telah dibangun dalam tradisionalitas (Wang Xian Jun, 2011: 8).

Perkembangan teknologi dan globalisasi adalah suatu sisi mata uang yang tidak dapat dipisahkan. Globalisasi mengandalkan sebuah tantangan baru, dimana media menjadi agen kebudayaan untuk menghancurkan identitas tradisional, sekaligus membangun kembali identitas baru. Modernitas menjadikan identitas sebagai masalah personal sekaligus teoritis, individu menjadi ragu dengan identitasnya dan karenanya individu dapat berubah identitasnya kapan saja (Wang Xian Jun, 2011: 9).

Dunia pendidikan yang semakin maju dan berkembang di pasar global, menuntut pendidikan di Indonesia untuk bangkit dari keterpurukan akan ilmu pengetahuan dan teknologi, karena semakin terpuruknya pendidikan di Indonesia, maka semakin besar peluang penjajah untuk menguasai dan mencuci otak kita, hal ini disebabkan karena minimnya sumber daya manusia yang mampu mengoperasikan alat teknologi yang canggih dan sarana untuk mengembangkan alat informasi dan teknologi tersebut (Armai Arief, 2007: 2)

\section{TINJAUAN TEORITIS}

\section{Manajemen}

Dari segi bahasa manajemen berasal dari bahasa Inggris yang merupakan terjemahan langsung dari kata management yang berarti pengelolaan, ketata laksanaan, atau tata pimpinan. Sementara dalam kamus Inggris Indonesia karangan John M. Echols dan Hasan Shadily management berasal dari akar kata to 
manage yang berarti mengurus, mengatur, melaksanakan, mengelola, dan memperlakukan.

Ramayulis (2008: 362), menyatakan bahwa pengertian yang sama dengan hakikat manajemen adalah al-tadbir (pengaturan). Kata ini merupakan derivasi dari kata dabbara (mengatur) yang banyak terdapat dalam Al Qur'an seperti firman Allah SWT, "Dia mengatur urusan dari langit ke bumi, kemudian (urusan) itu naik kepadanya dalam satu hari yang kadarnya adalah seribu tahun menurut perhitunganmu." (Q.S.AI Sajdah:05).

Dari isi kandungan ayat di atas dapatlah diketahui bahwa Allah SWT adalah pengatur alam (manager). Keteraturan alam raya ini merupakan bukti kebesaran Allah SWT dalam mengelola alam ini. Namun, karena manusia yang diciptakan Allah SWT telah dijadikan sebagai khalifah di bumi, maka dia harus mengatur dan mengelola bumi dengan sebaik-baiknya sebagaimana Allah mengatur alam raya ini.

Sementara manajemen menurut istilah adalah proses mengkordinasikan aktifitas-aktifitas kerja sehingga dapat selesai secara efesien dan efektif dengan dan melalui orang lain (Robbin dan Coulter 2007: 8).

Sedangkan Sondang $\mathrm{P}$ Siagian mengartikan manajemen sebagai kemampuan atau keterampilan untuk memperoleh suatu hasil dalam rangka mencapai tujuan melalui kegiatan-kegiatan orang lain

Bila diperhatikan dari kedua pengertian manajemen di atas maka dapatlah disimpulkan bahwa manajemen merupkan sebuah proses pemanfaatan semua sumber daya melalui bantuan orang lain dan bekerjasama dengannya, agar tujuan bersama bisa dicapai secara efektif, efesien, dan produktip. Sedangkan pendidikan Islam merupakan proses transinternalisasi nilai-nilai Islam kepada peserta didik sebagai bekal untuk mencapai kebahagiaan dan kesejahteraan di dunia dan di akhirat.

Dengan demikian maka yang disebut dengan manajemen pendidikan Islam sebagaimana dinyatakan Ramayulis adalah proses pemanfaatan semua sumber daya yang dimiliki (ummat Islam, lembaga pendidikan atau lainnya) baik perangkat keras maupun lunak. Pemanfaatan tersebut dilakukan melalui kerjasama dengan orang lain secara efektif, efisien, dan produktif untuk mencapai kebahagiaan dan kesejahteraan baik di dunia maupun di akhirat (Ramayulis 2008: 260).

\section{Facebook}

Facebook adalah fenomena baru internet. Website ini merupakan situs jaringan sosial dimana para pengguna dapat bergabung dalam komunitas seperti kota, kerja, sekolah, dan daerah untuk melakukan koneksi dan berinteraksi dengan orang lain (Eunike Eni, dkk 2009,: hlm. 1) Facebook juga merupakan salah satu layanan jejaring sosial yang sedang populer pada beberapa tahun ini. Meski tergolong baru, 
bukan berarti bahwa situs ini terseok-seok mengejar para pendahulunya (Andi Wicaksono, 2009: 9).

\section{Pembelajaran Pendidikan Agama Islam}

Pembelajaran merupakan proses kegiatan belajar mengajar, bertindak mengajar atau membelajarkan, mengevaluasi hasil belajar yang berupa dampak pengajaran. Peran siswa adalah bertindak belajar, yaitu mengalami proses belajar, mencapai hasil belajar, dan menggunakan hasil belajar yang digolongkan sebagai dampak pengiring. Dengan belajar, maka kemampuan mental semakin meningkat. Hal itu sesuai dengan perkembangan siswa yang beremansipasi diri sehingga ia menjadi utuh dan mandiri (Dimyati, Mudjiono, 2009: 5).

Langkah-langkah pembelajaran berdasarkan teori kondisioning operan sebagai berikut; a) Mempelajari keadaan kelas. Guru mencari dan menemukan perilaku siswa yang positif atau negatif. Perilaku positif akan diperkuat dan perilaku negatif akan diperlemah atau dikurangi, b) Membuat daftar penguat positif. Guru mencari perilaku yang lebih disukai oleh siswa, perilaku yang kena hukuman, dan kegiatan luar sekolah yang dapat dijadikan penguat, c) Memilih dan menentukan urutan tingkah laku yang dipelajari serta jenis penguatnya, dan d) Membuat program pembelajaran. Program pembelajaran ini berisi urutan perilaku yang dikehendaki, penguatan, waktu mempelajari perilaku, dan evaluasi. Dalam melaksanakan program pembelajaran, guru mencatat perilaku dan penguat yang berhasil dan tidak berhasil. Ketidakberhasilan tersebut menjadi catatan penting bagi modifikasi perilaku selanjutnya. (Dimyati, Mudjiono, 2009: 9).

Dalam mengajarkan suatu pelajaran, diperlukan adanya metode-metode pembelajaran yang bervariasi, hal ini dilakukan agar siswa tidak bosan dalam mengikuti kegiatan belajar selama berlangsung, berikut ini metode-metode pembelajaran yang harus diterapkan kepada siswa di antaranya; 1) Metode Ceramah. Metode ceramah yang berasal dari kata lecture, memiliki arti dosen atau metode dosen. Metode ini lebih banyak dipergunakan dikalangan dosen, karena dosen memberikan kuliah mimbar dan disampaikan melalui ceramah dengan pertimbangan dosen berhadapan dengan banyak mahasiswa yang mengikuti perkuliahan. Metode ceramah ini berbentuk penjelasan konsep, prinsip, dan fakta. Namun demikian pada sekolah tingkat lanjutan metode ceramah dapat dipergunakan oleh guru, dan metode ini divariasi dengan metode lain, 2) Metode demonstrasi dan eksperimen. Penggunaan metode demonstrasi dapat diterapkan dengan syarat memiliki keahlian untuk mendemonstrasikan penggunaan alat atau melaksanakan kegiatan tertentu seperti kegiatan yang sesungguhnya. Keahlian 
mendemonstrasikan tersebut harus dimiliki oleh guru dan pelatih yang ditunjuk, setelah didemonstrasikan, siswa diberi kesempatan untuk melakukan latihan keterampilan seperti yang diperagakan oleh guru atau pelatih, 3) Metode Tanya Jawab. Metode Tanya jawab dapat dinilai sebagai metode yang tepat, apabila pelaksanaannya ditujukkan untuk antara lain; 1) Meninjau ulang pelajaran atau ceramah yang lalu, agar siswa memusatkan lagi perhatian pada jenis dan jumlah kemajuan yang telah dicapai sehingga mereka dapat melanjutkan pelajarannya, 2) Menyelingi pembicaraan agar tetap mendapatkan perhatian siswa, atau dengan perkataan lain untuk mengikut sertakan mereka, c) Mengarahkan pengamatan dan pemikiran mereka, 4) Metode penampilan. Metode penampilan adalah berbentuk pelaksanaan praktek oleh siswa di bawah bimbingan dari dekat oleh pengajar. Praktek tersebut dilaksanakan atas dasar penjelasan atau demonstrasi yang diterima atau diminati siswa. Metode penampilan ini tepat digunakan manakala; a) Pelajaran telah mencapai tingkat lanjutan, 2) Kegiatan pembelajaran bersifat formal, latihan kerja, atau magang, 3) Siswa mendapat kemungkinan untuk menerapkan apa yang dipelajarinya ke dalam situasi sesungguhnya, 4) Metode Diskusi. Metode diskusi merupakan interaksi antara siswa dan siswa atau siswa dengan guru untuk menganalisis, memecahkan masalah, menggali atau memperdebatkan topik atau permasalahan tertentu, 4) Metode studi mandiri. Metode studi mandiri berbentuk pelaksanaan tugas membaca atau penelitian oleh siswa tanpa bimbingan atau pengajaran khusus, 5) Metode pembelajaran terprogram. Metode pembelajaran terprogram menggunakan bahan pengajaran yang disiapkan secara khusus. Isi pengajaran di dalamnya harus dipecahkan menjadi langkah-langkah kecil, dan diikuti dengan umpan balik segera. Siswa mendapat kebebasan untuk belajar menurut kecepatan masing-masing, 6) Metode Simulasi.Metode simulasi ini menampilkan simbol-simbol atau peralatan yang menggantikan proses, kejadian, atau benda yang sebenarnya) Metode Studi Kasus. Metode ini berbentuk penjelasan tentang masalah, kejadian, atau situasi tertentu, kemudian siswa ditugasi mencari alternatif pemecahannya, 7)Metode simposium. Metode simposium adalah metode yang memaparkan suatu seri pembicara dalam berbagai kelompok topik dalam bidang materi tertentu. Materi-materi tersebut disampaikan oleh ahli dalam bidangnya, setelah itu peseta dapat menyampaikan pertanyaan dan sebagainya kepada pembicara (Martinis Yamin, 2004: 65-77).

\section{Pengelolaan Facebook ada Proses Pembelajaran}

Menghadapai semua persoalan pendidikan, maka pemerintah melalui Kementrian Pendidikan dan Kebudayaan mengatur dan menyusun strategi untuk mengembangkan pendidikan di Indonesia yaitu dengan memberikan fasilitas social 
network atau situs jejaring sosial, agar pendidikan di Indonesia maju dan berkembang serta mampu menguasai alat teknologi yang canggih untuk dapat memperkaya ilmu pengetahuan dan wawasan bagi (Martinis Yamin, 2004: 65-77).

Arus globalisasi yang semakin menyebar di seluruh penjuru dunia, menuntut pendidkan di Indonesia harus lebih waspada dalam menyikapi perkembangan zaman yang semakin maju. Untuk itu pemerintah memberikan perhatian besar terhadap pendidikan di Indonesia. Bentuk perhatian tersebut ditunjukkan oleh pemerintah dengan menyediakan layanan jejaring sosial yang semakin banyak dipublikasikan dan dimanfaatkan oleh semua lapisan masyarakat (Martinis Yamin, 2004: 65-77).

Layanan jejaring sosial yang disediakan oleh pemerintah, ternyata mampu membius warga Indonesia untuk berlomba-lomba dalam menguasai situs jejaring sosial seperti internet, facebook, twitter, Friendster dan lain-lain, terutama jejaring facebook yang sedang booming di negeri ini. Namun seiring dengan kemajuan teknologi yang canggih, ternyata kecanggihan alat teknologi dapat membawa dampak positif dan negatif. Positif dipandang jika alat teknologi digunakan untuk proses pembelajaran yang dapat membantu memperbanyak ilmu pengetahuan, akan tetapi dipandang negatif jika alat teknologi dimanfaatkan untuk hal-hal yang menjurus pada keburukan dan kemaksiatan seperti mengupload video-video mesum, mencari lawan jenis untuk dijadikan pacar dan hal-hal negatif lainnya yang dapat merusak pikiran dan akhlak moral anak bangsa. (Martinis Yamin, 2004: 6577).

Tidak dapat dipungkiri, menjamurnya situs jejaring sosial seperti Internet, facebook, twitter, friendster dan lain-lain, semuanya itu sesuai dengan arus global dan perkembangan zaman yang terjadi di jagad raya ini. Berbicara masalah situs jejaring sosial, maka fenomena yang sedang booming di seantero jagad raya ini adalah situs jejaring facebook. Facebook menjadi trend di kalangan masyarakat baik dalam maupun luar negeri. Keberadaan facebook mampu menghipnotis mayarakat Indonesia khususnya, karena selain fiturnya yang banyak, situs jejaring pertemanan ini sangat mudah sekali untuk dioperasikan, sehingga wajar jika situs pertemanan facebook ini banyak sekali digandrungi oleh seluruh lapisan masyarakat, mulai dari anak-anak, remaja sampai orang dewasa (Desy Arisandy, 2009: 11).

Facebook mulai berdiri pada tahun 2004 oleh seorang mahasiswa dari Universitas Harvard yang bernama Mark Zuckerberg. Situs ini langsung berkembang pesat dari awal didirikannya sampai pada saat ini. Perkembangan situs jejaring facebook ini bisa dilihat dengan tabel perkembangan para pendaftar dan 
pengguna facebook yang setiap hari semakin banyak orang yang memanfaatkan waktunya di dunia maya. (Ridwan Sanjaya, 2009: 2).

Dalam dunia pendidikan, facebook merupakan sarana atau alat yang bisa dijadikan sebagai media pembelajaran bagi untuk menambah ilmu pengetahuan dan wawasan informasi yang luas. Dengan facebook kita bisa bertukar pikiran dengan sangat mudah, seperti menulis catatan diari, membuat puisi dan mengisi kuis-kuis yang sudah ada di facebook. (Ridwan Sanjaya, 2009: 2).

Saat ini zaman teknologi informasi sudah sangat mobile, facebook tidak hanya dibaca di laptop tapi juga di Blackberry atau telepon seluler. Kondisi ini membuat sebagian siswa sibuk sendiri dengan Blackberry atau handphonennya di ruang belajar untuk mengupdate status atau membuat komentar atau menulis di halaman facebook temannya. Tidak jarang kita temui di tempat umum, seusia anak sekolah sibuk dengan Blackberrynya walaupun saat itu sedang berjalan dengan temannya. (Ridwan Sanjaya, 2009:2).

Facebook bisa menjadi alat untuk melatih mengekspresikan diri, hanya saja terkadang cara penyampaian dan waktunya tidak jelas dalam menggunakan facebook, bukan saat istirahat saja, tapi dimana dan kapan saja baik di ruang kelas maupun di luar kelas, sehingga ketika pelajaran berlangsung, siswa tidak dapat lagi berkonsentrasi dalam menerima pelajaran. Bahkan prestasi siswa yang awalnya bagus, setelah mengenal dan menjadi pengguna facebook, maka tingkat belajar siswa menjadi menurun drastis. Hal ini disebabkan karena penggunaan facebook yang terlalu berlebihan dan kurangnya pengawasan dari orang tua atau guru-guru, sehingga siswa bebas menggunakan facebook setiap harinya.

Oleh sebab itu facebook dalam sebuah pendidikan terdapat manfaat dan bahaya, bahaya dari penggunaaan facebook yaitu siswa menjadi terbengkalai dengan kewajibannya untuk belajar, sehingga menyebabkan prestasi belajar siswa menurun, adapun manfaat dari penggunaan facebook yaitu dapat membantu siswa mencari dan menggali informasi serta pengetahuan yang luas (Andi Wicaksono 2009: 45). Sehingga dalam hal ini tergantung dari manajemen pengguna.

Namun jika dilihat dari realita yang ada, maka perkembangan facebook di dunia pendidikan bagi siswa khususnya, kurang berhasil pemanfaatannya, karena kebanyakan siswa justru terpuruk kondisinya setelah menjadi facebooker. Hal ini karena pengawasan yang kurang baik di lingkungan keluarga maupun lingkungan sekolah, sehingga siswa yang teradiksi dengan facebook cenderung malas untuk belajar dan psikologinyapun menjadi terganggu. Akan tetapi jika siswa mampu menggunakan facebook dengan baik dan facebook menjadi motivator untuk bahan belajarnya, serta kondisi lingkungan keluarga yang mendukung, maka facebook 
bias dijadikan sebagai sumber media untuk perkembangan siswa (Andi Wicaksono 2009: 45).

Facebook merupakan salah satu jejaring sosial atau social network yang sangat populer di kalangan masyarakat Indonesia sekarang ini. Keberadaan facebook saat ini banyak digandrungi oleh semua lapisan masyarakat, mulai dari tingkat bawah sampai pada tingkat atas, karena selain menjadi hiburan, facebook juga bisa dijadikan sebagai ajang menggali potensi bagi para pengguna facebook, dan juga sebagai alat yang mempunyai manfaat untuk dijadikan sebagai sumber media pembelajaran bagi pendidikan (Arisandy 2009: 4).

Sejak munculnya facebook di dunia maya, semua perhatian tertuju kepada situs pertemanan ini, mulai dari anak-anak, remaja, dewasa bahkan sampai pada usia lanjutpun menyukai dan menjadi user atau pengguna facebook yang aktif setiap harinya di layar jaringan facebook. Sebenarnya kejadian ini hampir sama terjadi ketika booming pendahulunya yaitu friendster. Namun ada perbedaan yang mencolok pada kedua situs jejaring tersebut.

Di facebook selalu ada aktifitas pemutakhiran secara berkala. Tidak dalam hitungan tahun, tapi dalam hitungan bulan selalu ada penambahan fitur baru dalam layanan jejaring sosial ini. Selain pemutakhiran berkala, facebook juga menawarkan kemudahan kepada penggunanya. Situs jejaring sosial ini memang sangat mudah dipahami dan mudah dalam mengaplikasikannya.

Akan tetapi pada situs ini terdapat manfaat dan bahaya dalam penggunaannya. Manfaat facebook siswa dapat memperluas ilmu pengetahuan, serta menggali informasi-informasi yang bermanfaat untuk perkembangan siswa. Adapun bahaya dalam menggunakan facebook yaitu dapat menurunkan produktifitas setiap individu, dalam hal ini siswa yang teradiksi facebook akan merasa kesulitan dalam hal belajar dan mengatur waktu luangnya untuk mengerjakan sesuatu yang positif, sehingga ketergantungan pada facebook tersebut membawa dampak buruk bagi siswa, akibatnya prestasi belajarnya mulai merosot dan psikologinya menjadi terganggu (Arisandy 2009: 4).

Siswa belajar secara interdependent dan bersama-sama menghayati persepsi terhadap realitas kehidupan dan memperhatikan persepsi orang lain, kemudian merevisi sikap pandangnya sendiri dari hasil belajarnya. Jadi corak belajar demikian adalah bersifat inovatif, bukan belajar melestarikan apa yang ada konservatif, dan pasif serta dogmatis (Muzayyin Arifin, 2007: 33).

Pada dasarnya pola pelaksanaan pendidikan Islam dapat menggabungkan dalam waktu bersamaan antara pendidikan kejiwaan dengan pembersihan ruh (jiwa), menumbuhkan kecerdasan pikiran, dan memperkuat jasmani. Pendidikan 
Islam dimulai dari keluarga (rumah) dimana anak-anak menerima pengaruh dari apa yang dilakukan oleh kedua orang tuanya dengan cara meniru dan menerima pelajaran. Shalat merupakan pelajaran yang pertama-tama diberikan kepada anak sejak masa kecil, karena sholat merupakan rukun Islam yang kedua (yang menjadi tiangnya agama). (Al-Jumbulati 2002: 2).

Dalam dunia pendidikan, keberadaan facebook bisa dijadikan sebagai media pembelajaran bagi siswa, hal ini jika penggunaan facebook bisa difungsikan untuk kegiatan yang positif seperti ajang mengekspresikan diri, dengan menulis puisi, catatan pengetahuan yang belum diajarkan di sekolah dan sebagainya, sehingga siswa dapat membuka pikirannya dan menggali potensinya untuk memperkaya wawasan dan pengetahuannya.

Namun, tidak banyak para pengguna facebook yang bisa memanfaatkan waktunya untuk melakukan kegiatan yang positif. Sebaliknya keberadaan facebook bisa menjadi ancaman bagi para pengguna facebook, sehingga melalaikan tugas utama bagi seorang siswa yaitu belajar. Dengan demikian prestasi belajarnya akan menurun. Padahal prestasi merupakan tolak ukur siswa dalam sebuah pendidikan untuk mencapai suatu keberhasilan.

Banyak pengguna internet di Indonesia, bahkan juga dunia, saat ini terjangkiti wabah facebook. Padahal situs jaringan pertemanan sejenis yang dulu juga pernah populer, friendster, tidak menciptakan dampak yang sedahsyat facebook. Berbeda dengan friendster, facebook terbukti bukan hanya menarik bagi anak-anak muda saja, tetapi juga bagi pengguna dewasa dari berbagai lapisan profesi (Ridwan Sanjaya 2009: 1).

Menurut data yang diperoleh dari insidefacebook.com., Indonesia merupakan negara yang tingkat pertumbuhan akun facebook yang tercepat di Asia Tenggara. Padahal, dahulunya pengguna internet di negeri ini merupakan penggemar fanatik layanan jaringan sosial friendster. Namun ajakan untuk bergabung atau melihat akun jaringan pertemanan ini tidak lagi mengarah pada friendster, tapi sudah berubah ke layanan facebook. (Ridwan Sanjaya 2009: 1).

\section{Manfaat Facebook}

Facebook memilliki beberapa manfaat sebagai media pembelajaran, yaitu antara lain;a) Dapat mempererat tali silaturahmi (persaudaraan) sekaligus mendapatkan informasi terbaru dari status orang lain, b) Facebook dapat digunakan sebagai media diskusi, dakwah, kampanye, tukar informasi, dan mengajak orang dalam kebaikan serta, sebagai media iklan dan promosi, 4) Melatih diri untuk berkomunikasi, baik itu dengan cara mengeluarkan pendapat maupun berkomentar 
mengenai berita ter-up to date, serta sebagai tempat untuk berlatih menulis juga, d) Facebook dapat digunakan untuk membangun jaringan atau komunitas baru antar para anggotanya, e) Berlatih diri untuk menggunakan bahasa asing, f) Sebagai tempat belajar, mendapatkan informasi baru mengenai tempat yang belum pernah kunjungi, dan dapat dilakukan dengan bertukar informasi dengan sesama teman, 7) Fasilitas atau fitur-fitur yang disediakan facebook jauh lebih lengkap bila dibandingkan dengan layanan jaringan sosial lainnya, facebook mampu memanjakan para penggunanya dengan layanan games, groups, chatting, dan lain sebagainya (Arisandy 2009: 63).

Melihat dari banyaknya manfaat yang didapatkan dari penggunaan facebook, maka dalam upaya mencari pengetahuan dan wawasan yang luas, hendaknya harus mengatur waktu untuk dapat menggunakan facebook dengan baik karena penggunaan facebook yang baik akan membawa dampak positif bagi siapa yang mampu mengontrol dan mengaplikasikannya.

\section{Bahaya Facebook}

Jaringan sosial (social networking) seperti facebook tentu tidak hanya memiiki segudang manfaat yang dapat dipetik oleh para penggunanya. Namun, di balik itu semua, ternyata facebook juga memiliki dampak negatif atau bahaya, di antaranya; a) Dapat mengurangi kinerja seseorang, karena terlalu banyaknya waktu untuk mengurus facebook sehingga dapat mengurangi waktu kerja itu sendiri, b) jaringan sosial seperti ini membuat individu semakin terisolasi. Ini terbukti dari waktu yang dihabiskan orang untuk berinteraksi langsung turun secara drastis semenjak adopsi media elektronik melonjak, c) Facebook memang telah berhasil menggeser senior jaringan pertemanan yang lain seperti Friendster karena kelebihannya dalam feature-nya. Namun facebook juga memiliki efek candu negatif sehingga banyak waktu yang terbuang hanya untuk mengakses facebook, d) Kaburnya batasan ranah pribadi. Seperti yang telah diketahui, dalam facebook, setiap orang bebas untuk menuliskan apa saja tanpa ada larangan dan hukuman. Sehingga, terkadang, tanpa sadar menuliskan hal-hal pribadi, yang seharusnya tidak dituliskan dan disampaikan di ranah publik, e) Dalam dunia maya, segala bentuk pemalsuan kerap terjadi, melalui foto misalnya. Seseorang yang berniat tidak baik dapat dengan mudahnya mengambil foto orang lain, kemudian mengeditnya untuk kepentingankepentingan negatif, f) Facebook ternyata relatif mudah untuk dimasuki oleh spyware. Ini karena bentuknya sama seperti aplikasi, dan 7) Layaknya seperti email, facebook pun kerap diserang oleh spam. (Arisandy 2009: 63). 
Pertumbuhan facebook yang sangat luar biasa mau tidak mau menarik perhatian tokoh-tokoh masyarakat di tanah air, termasuk tokoh agama. Sebagai penjaga moral masyarakat, ulama merasa bertanggung jawab dan khawatir penggunaan facebook dapat merusak akhlak pengguna di Indonesia. Oleh karena itu muncul gagasan untuk mengeluarkan fatwa haram bagi facebook. Tentu rencana ini mengundang reaksi keras dari masyarakat, terutama para facebookers (pengguna facebook) (Tony Hendroyono 2009: 39).

Wacana fatwa facebook haram mengemuka setelah ulama tujuh ratus Ulama jawa Timur mengungkapkan bahwa bahwa facebook dapat memicu pergaulan bebas karena dapat berkomunikasi dengan lawan jenis yang bukan muhrim secara berlebihan. Namun badan yang berwenang mengeluarkan fatwa yaitu Majelis Ulama Indonesia (MUI) menilai bahwa tidak ada alasan yang mendasar untuk mengeluarkan fatwa haram jika jejaring sosial ini mengandung banyak manfaat bagi umat. Yang diharamkan itu bukan facebooknya, melainkan penggunaan hal-hal negatif yang terdapat di dalam facebook (Tony Hendroyono 2009: 39). Sebuah teknologi selalu mempunyai dua sisi yang berlawanan, jika ia jatuh ke tangan orang jahat, maka digunakan untuk kemudharatan, dan sebaliknya, jika teknologi di tangan yang benar, maka manfaat yang akan didapat. Oleh sebab itu, efek manfaat dan mudharat daripada facebook tergantung pada para pengguna itu sendiri (Tony Hendroyono 2009: 40).

\section{Efek Sosial Facebook}

Facebook sebagai salah satu media sosial memiliki beberapa efek yang perlu diketahui banyak orang, diantaranya;

a) Facebook bikin lupa belajar. Peneliti dari Ohio State Universiy, Aryn Karpinski, mengungkapkan bahwa facebook dapat membuat nilai seorang pelajar menurun, karena pelajar lebih banyak menghabiskan waktunya untuk mengakses facebook, sehingga waktu belajarnya sedikit(Tony Hendroyono 2009: 41)

b) Menurunkan Produktivitas

Bagi orang yang telah teradiksi, pasti akan melakukan berbagai cara untuk bisa selalu memperbarui akunnya, mereka cenderung tak kenal waktu, entah ketika jam kerja bagi orang kantoran, atau ketika jam pelajaran berlangsung bagi para siswa dan mahasiswa. Mereka lebih mementingkan akunnya daripada kewajiban yang diembannya. Hal ini tentunya berdampak pada produktivitas kerja dan belajar seseorang (Wicaksono 2009: 45).

c) Pengaruhi Kondisi Psikologis 
Baru-baru ini seorang pakar dari Inggris Aric Sigman telah merilis jurnal hasil risetnya mengenai pengaruh situs jejaring social seperti facebook dan sebagainya terhadap kesehatan manusia. Dalam jurnal tersebut dijelaskan bahwa situs semacam itu mampu memberikan dampak buruk terhadap kondisi kejiwaan si pengguna jika sampai tingkat tearadiksi. Kebiasaan bergaul via situs pertemanan tersebut berpotensi mengurangi kegiatan sosialisasi antar manusia di kehidupan nyata, sehingga hal ini akan berdampak pada kondisi biologis manusia, dampak tersebut antara lain dapat mengubah alur kerja gen, menghambat respons sistem imun, tingkat hormon dan lain-lain, namun dampak yang paling berbahaya adalah perubahan kondisi kejiwaan. (Wicaksono 2009: 51).

2) Ajang Ikhtilath (campur baur dalam pergulan)

Silaturahmi adalah kegiatan positif yang memang harus dibudayakan bagi masyarakat muslim. Banyak orang yang mengatakan bahwa melalui facebook kita bisa mempererat tali persaudaraan. Dengan alasan silaturahmi, maka para pengguna facebook dengan asyiknya bercakap-cakap tanpa merenungkan sejenak apa yang mereka lakukan itu, benar atau salah. Padahal ajang silaturrahmi ini bisa menimbulkan dampak negatif yang menjurus pada kemaksiatan (Wicaksono 2009: $51)$.

\section{METODOLOGI PENELITIAN}

Secara garis besar, data penelitian ini dikumpulkan dan kemudian diklasifikasikan ke dalam data kualitatif dan data kuantitatif (Anas Sudiono 2000: 15). Data kualitatif adalah data yang tidak berwujud dengan angka, berkenaan dengan gambaran umum lokasi penelitian, kegiatan observasi, wawancara dan studi dokumentasi. Sedangkan data kuantitatif adalah data yang dimodifikasi dalam angka, data diperoleh dari nilai prestasi siswa dan angket yang disebarkan. Penelitian ini dilaksanakan dari tanggal 20 Agustus sampai dengan tanggal 28 November 2015. Peneliti mengambil lokasi penelitian di Madrasah Aliyah (MA) Insan Takwa, Kecamatan Ciomas, Kabupaten Bogor.

Pelaksanaan penelitian ini memakai metode penelitian korelasi, dimana pada penelitian ini hasil data yang telah didapat dihitung guna mendapatkan bukti yang nyata sesuai dengan perumusan masalah. Pelaksanaan penelitian kuantitatif ini sangat sederhana, yang dimulai dari perumusan masalah, pengumpulan data dan analisis data untuk menjawab masalah, penyusunan laporan penelitian dan perumusan

Dalam penelitian ini, yang menjadi populasi adalah siswa kelas XI Madrasah Aliyah (MA) Insan Takwa, tahun pelajaran 2015-2016 yang berjumlah 58 orang. 
Untuk penentuan jumlah sampel, sebagaimana dikatakan oleh Suharsimi Arikunto (1993), yaitu kalau jumlah populasinya kurang dari 100, lebih baik dijadikan sebagai sampel semuanya, sehingga penelitiannya merupakan penelitian populasi (Suharsimi Arikunto 2002: 10). Dalam penelitian ini, mengingat jumlah populasinya hanya 58 siswa, maka seluruh populasi tersebut akan dijadikan sampel.

Variabel adalah suatu atribut atau sifat atau nilai dari orang, obyek atau kegiatan yang mempunyai variasi tertentu yang ditetapkan oleh peneliti untuk dipelajari dan kemudian ditarik kesimpulannya (Sugiyono 2009: 61).

Variabel bebas $(X)$ adalah variabel yang mempengaruhi atau yang menjadi sebab perubahannya atau timbulnya variabel dependen (terikat). Dalam SEM (Structural Equation Modelling atau pemodelan) persamaan struktural, variabel independen disebut juga sebagai variabel eksogen. Variabel bebas dalam penelitian ini adalah manajemen penggunaan facebook.

Variabel terikat $(Y)$ merupakan variabel yang dipengaruhi atau yang menjadi akibat, karena adanya variabel bebas. Dalam SEM (Structural Equation Modelling atau pemodelan) persamaan struktural, variabel dependen disebut juga sebagai variabel indogen. Variabel terikat dalam penelitian ini adalah pembelajaran peserta didik terhadap mata pelajaran PAI.

Pengumpulan data yang diperlukan untuk mengungkap pengaruh facebook terhadap pembelajaran siswa pada mata pelajaran Pendidikan Agama Islam (PAI) kelas XI, Madrasah Aliyah (MA) Insan Takwa, Kecamatan Ciomas, Kabupaten Bogor, menggunakan beberapa teknik antara lain; 1) Observasi. Observasi yang dilakukan adalah observasi partisipasi, yaitu peneliti ikut terlibat dalam kegiatan yang diamatinya. Hal ini penting karena dapat mengamati langsung secara obyektif kondisi sebenarnya yang terdapat di lokasi penelitian. Adapun yang akan diobservasi adalah sekolah, guru dan siswa-siswa kelas XI, Madrasah Aliyah (MA) Insan Takwa, Kecamatan Ciomas, Kabupaten Bogor, 2) Interview. Untuk mendapatkan data yang lebih riil lagi, peneliti dalam penelitian ini melakukan interview (wawancara) langsung terhadap pihak sekolah, guru, dan siswa yang berhubungan dengan penelitian ini, 3) Angket. Dalam penelitian ini digunakan angket yang disebarkan untuk kemudian diberikan isian oleh siswa kelas XI, Madrasah Aliyah (MA) Insan Takwa. Sebelum diisi, terlebih dahulu dijelaskan tentang cara pengisiannya. Angket ini berisi tentang hal-hal yang terkait dengan penggunaan facebook terhadap pembelajaran siswa pada mata pelajaran Pendidikan Agama Islam (PAI), dan 4) Dokumentasi, yakni suatu usaha aktif baik suatu badan atau lembaga dengan menyajikan hasil pengolahan bahan-bahan dokumen yang bermanfaat bagi badan atau lembaga yang mengadakan. 
Dokumentasi ini dilakukan untuk memperoleh data sejarah didirikannya Madrasah Aliyah (MA) Insan Takwa, keadaan sarana dan prasarana, data-data guru, murid, dan kurikulum yang digunakan, serta hal lainnya yang terkait.

\section{Teknik Analisis Data}

\section{Editing}

Dalam mengolah data, yang pertama harus dilakukan adalah memilih data-data yang terpakai. Sedangkan data-data yang tidak terpakai dihilangkan, Sehingga akan memudahkan proses pengolahan data. Dalam hal ini adalah daftar pertanyaan yang terdapat dalam angket (kuesioner). Kuesioner yang dibuat sebanyak 15 soal yang kemudian diedit menjadi 10 soal.

\section{Skoring}

Kuesioner yang digunakan didesain berdasarkan skala model Likert yang berisi sejumlah pernyataan yang menyatakan obyek yang hendak diungkap, kemudian diberikan skor dari masing-masing jawaban yang disediakan dalam angket. Yaitu dengan memberi kode atau skor terhadap jawaban-jawabam dari angket (kuesioner) yang diberikan kepada responden berupa simbol atau angka. Simbol atau angka itu disebut Kode (Masri Singaribun dan Sofian Effendi, 2008: 219).

Penskoran atas kuesioner skala model Likert yang digunakan dalam penelitian ini merujuk pada empat alternatif jawaban, sebagaimana terlihat di bawah ini:

Tabel 1.

Skooring data

\begin{tabular}{|c|c|c|}
\hline Alternatif Jawaban & Keterangan & Skor \\
\hline A & Ya & 4 \\
\hline B & Kadang-kadang & 3 \\
\hline C & Tidak & 2 \\
\hline D & Tidak tahu & 1 \\
\hline
\end{tabular}

\section{Tabulating}

Setelah data terkumpul, dan diberi skor kemudian data-data yang terkumpul dimasukan ke dalam tabel. Hal ini dimaksudkan untuk mempermudah dalam mengolah data serta dalam mengintepretasikan data-data yang diperoleh. Untuk mengolah data peneliti menggunakan cara pendeskripsian data, hal ini dimaksudkan untuk mempermudah sehingga terlihat gambaran secara sistematis data yang diperoleh. 


\section{Analisa Parsial/Rumus Prosentase}

Data yang dihasilkan dari setiap item pernyataan yang ditanyakan selanjutnya ditabulasikan dengan menggunakan rumus prosentase kemudian dianalisa dan diinterpretasikan secara deskriptif analisis. Rumusnya adalah:

$$
P=F / N \times 100 \%
$$

\section{Keterangan :}

$$
\begin{array}{lll}
\mathrm{P} & = & \text { Prosentase } \\
\mathrm{F} & = & \text { Frekwensi/Jumlah yang mengisi } \\
\mathrm{N} & = & \text { Jumlah Responden } \\
\% & = & \text { Bilangan Tetap (konstanta) }
\end{array}
$$

Dengan kategori sebagai berikut :

$$
\begin{aligned}
& 0 \%-25 \%=\text { Kurang } \\
& 26 \%-50 \%=\text { Cukup baik } \\
& 51 \%-75 \%=\text { Baik } \\
& 76 \%-100 \%=\text { Sangat baik }
\end{aligned}
$$

\section{Menghitung Rata-rata}

Hasil skor jawaban yang telah dikumpulkan, selanjutnya akan dihitung dan dicari rata-ratanya untuk diketahui sejauh mana siswa menggunakan facebook untuk kegiatan belajar, dengan kategori nilai sebagai berikut:

Tabel 2

Rank Skor Data

\begin{tabular}{|l|c|}
\hline \multicolumn{1}{|c|}{$\begin{array}{c}\text { Besarnya "r" } \\
\text { Product Moment }\left(\mathbf{r}_{\mathbf{x y}}\right)\end{array}$} & Interpretasi \\
\hline Antara 0,800 sampai dengan 1,00 & Tinggi \\
\hline Antara 0,600 sampai dengan 0,800 & Cukup \\
\hline Antara 0,400 sampai dengan 0,600 & Agak rendah \\
\hline Antara 0,200 sampai dengan 0,400 & Rendah \\
\hline Antara 0,000 sampai dengan 0,200 & Sangat rendah \\
\hline
\end{tabular}

Apabila nanti saat perhitungan diperoleh angka negatif, berarti korelasinya negatif. Ini menunjukan adanya kebalikan urutan. Indeks korelasi tidak mungkin lebih dari 1,00. (Suharsini Arikunto, 2002: 276).

Untuk mengetahui korelasi atau hubungan antara facebook dengan prestasi belajar siswa digunakan rumus Korelasi Product Moment dengan Angka Kasar yang rumusnya sebagai berikut: 


$$
r_{x y}=\frac{\mathrm{N} \sum \mathrm{XY}-\left(\sum \mathrm{X}\right)\left(\sum \mathrm{Y}\right)}{\sqrt{\left\{\mathrm{N} \sum \mathrm{X}^{2}-\left(\sum \mathrm{X}\right)^{2}\right\}\left\{\mathrm{N} \sum \mathrm{Y}^{2}-\left(\sum \mathrm{Y}\right)^{2}\right\}}}
$$

\section{Keterangan:}

$\Gamma \mathbf{x y}=$ Angka indeks korelasi "r" Product Moment (Koefisien korelasi antara $\mathrm{X}$ dan $\mathrm{Y}$ ).

$\mathbf{N}=$ Number of cases (jumlah subyek)

$\mathbf{X}=$ Skor Butir

$\mathbf{Y}=$ Skor Total

$\sum \mathbf{X Y}=$ Jumlah hasil perkalian antara skor $\mathrm{X}$ dan skor $\mathrm{Y}$

$\Sigma \mathbf{X}=$ Jumlah seluruh skor $\mathbf{X}$

$$
\Sigma \mathrm{Y}=\text { Jumlah seluruh skor } \mathrm{Y}
$$

\section{SIMPULAN}

Dari hasil penelitian yang telah dilakukan dan ditunjang dengan beberapa landasan teoritis yang dikemukakan mengenai manajemen penggunaan facebook terhadap pembelajaran pendidikan di sekolah Madrasah Aliyah (MA) Insan Takwa, maka dapat ditarik kesimpulan berdasarkan rumusan masalah yang telah dibuat sebagai berikut:

Dengan pencapaian skor 40,57 yang menjawab Ya, maka dapat disimpulkan hubungan penggunaan facebook dengan prestasi belajar siswa Pendidikan Agama Islam di Madrasah Aliyah (MA) Insan Takwa positif berngaruh dan hal ini tergolong cukup baik.

Dengan skor nilai rata-rata prestasi siswa terhadap pembelajaran Pendidikan Agama Islam yaitu sebesar 75,71, maka dapat disimpulkan bahwa dampak penggunaan facebook terhadap prestasi belajar Pendidikan Agama Islam Siswa kelas XI di Madrasah Aliyah (MA) Insan Takwa tergolong baik.

Untuk mengetahui hubungan yang signifikan antara penggunaan facebook dengan prestasi belajar Pendidikan Agama Islam, maka dapat diketahui dengan memperhatikan besarnya $\Gamma_{\mathrm{xy}}$ (yaitu 0,16 ) berarti koefisien korelasi sebesar 0.16 bila dibandingkan dengan tabel interpretasi koefisien korelasi $0,00<0,16<0,20$ (koefisien korelasi sangat rendah), berarti antara variabel $X$ dan variabel $Y$ termasuk berkorelasi positif yang sangat rendah. Selanjutnya jika dikonsultasikan dengan tabel angka kritik " $r$ " Product Moment dari Pearson pada taraf signifikansi $5 \%$ dan $N=58$, maka diperoleh $\mathbf{r}$ tabel $=0,05$. Dengan demikian " $r$ " hitung $>$ " $r$ " tabel $(0,16>0,05)$. Ini berarti hipotesis $(\mathrm{Ho})$ diterima atau disetujui, sedangkan hipotesis alternatif ditolak, berarti bahwa pada taraf signifikansi 5\% memang terdapat pengaruh positif yang kurang signifikan antara variabel $\mathrm{X}$ (facebook) dan 
variabel $Y$ (pembelajaran peserta didik pada mata pelajaran Pendidikan Agama Islam).

\section{DAFTAR PUSTAKA}

Alqarny, 'Aidh. (2011). Kado Istimewa Untuk Kawula Muda. Jakarta: Embun Litera. Al-Abrasy, Athiyah, Mohammad. (1987). Dasar-Dasar Pokok Pendidikan Islam. Jakarta: Bulan Bintang.

Al-Jumbulati, Ali, et.al., (2002). Perbandingan Pendidikan Islam. Jakarta: Rineka Cipta.

Anonimus. (2012). Sisi Gelap Facebook. Jakarta: Elek Media Komputindo. (2009). Gara-Gara Facebook. Yogyakarta: Gravina Media Cipta.

Arisandy, Desy. (2009). Top Bak Artis Beken Dengan Facebook. Jogjakarta: Garailmu.

Arifin, Muzayyin. (2007). Kapita Selekta Pendidikan Islam. Jakarta: Bumi Aksara.

Arifin, (2008). IImu Pendidikan Islam. Jakarta: Bumi Aksara.

Arikunto, Suharsimi. (2002). Prosedur penelitian Suatu Pendekatan Praktik, Jakarta: Rineka Cipta.

Armai, Arief. (2007) Reformulasi Pendidikan Islam, Ciputat Press, Jakarta.

Sanjaya, Ridwan. (2009). Panduan Cepat Menguasai Facebook. Jakarta: PT Elek Media Komputindo.

Sanjaya, Ridwan. (2009). Bisnis Menggunakan Facebook. Jakarta: PT Elex Media Komputindo.

Soenarjo, et.al., (1971). Al-Quran Terjemahan. Jakarta: Yayasan Penyelenggara Penerjemah/Penafsir Al Quran.

Daradjat, Zakiah. et al., (2006). IImu Pendidikan Islam. Jakarta: Bumi Aksara.

Dimyati, Mudjiono. (2009). Belajar dan Pembelajaran. Jakarta: Rineka Cipta.

Eni, Eunike, Wahyono, Teguh. (2009). Kupas Tuntas Facebook. Yogyakarta: Gava Media.

Fahri, Yasser, M. (2009). Muhammad Saw on Facebook. Jakarta: Mizan Publika. Hendroyono, Tony.(2009). Facebook Haram. Yogyakarta: Bentang Pustaka. Tony. (2009). Facebook. Yogyakarta: Bentang Pustaka.

Majid Abdul, Andayani Dian. (2004). Pendidikan Agama Islam Berbasis Kompetensi. Bandung: Remaja Rosdakarya.

Mardalis, (2006). Metode Penelitian Suatu Pendekatan Proposal. Jakarta: Bumi Aksara. 
Purwanto, Ngalim. (2000). Prinsip-Prinsip dan Teknik Evaluasi Pengajaran. Bandung: Remaja Rosdakarya.

Ramayulis, (2004). IImu Pendidikan Islam. Jakarta: Kalam Mulia.

Robbin dan Coulter (2007), Manajemen (edisi kedelapan), PT Indeks.

Sudiono, Anas. (2000). Pengantar Statistik Pendidikan. Jakarta: Grafindo Persada.

Sugiyono, (2009). Metode Penelitian Pendidikan. Bandung: Alfabeta.

Sondang P Siagian (1990), Filsafah Administrasi, CV Masaagung

Syar'i, Ahmad, (2005). Filsafat Pendidikan Islam. Jakarta: Pustaka Firdaus.

Tafsir, Ahmad. (2006). Filsafat Pendidikan Islam. Bandung: Remaja Rosdakarya.

Uhbiyati, Nur. (1998). IImu Pendidikan Islam. Bandung: Pustaka Setia.

Wang Xiang Jun, (2011). Hipnotis Marketing Yahudi Malalui Facebook. Yogyakarta:

Pustaka Radja.

Wicaksono, Andi. (2009). Bahaya Facebook. Solo: PT. Aqwam Media Profetika.

Yasmin, Martinis. (2003). Strategi Pembelajaran Berbasis Kompetensi. Jakarta: Gaung Persada Press.

Yunus, Mahmud. (1983). Metode Khusus Pendidikan Agama. Jakarta: Hidakarya Agung.

Zuhairini, et al., Metodik Khusus Pendidikan Agama (Surabaya: Biro Ilmiah fakultas IAIN Sunan Ampel Malang) 